\title{
FACING BACK TO MOVE FORWARD: EVALUATING THE CONTRIBUTION OF THE INTERNATIONAL CRIMINAL TRIBUNAL OF RWANDA ON THE EVOLUTION OF INTERNATIONAL CRIMINAL LAW
}

\author{
by Dan Ngabirano*
}

'There can be no healing without peace, there can be no peace without justice and there can be no justice without respect and the rule of law.'

- Kofi Annan

\section{Introduction}

The 1994 Rwanda genocide is one of the worst human catastrophes to have befallen mankind since World War II. The genocide left over 800 000 people dead, ${ }^{1} 1.7$ million displaced, 400000 widowed, and 130 000 arrested on suspicion of committing acts of genocide. The consequences of this genocide are still felt today. ${ }^{2}$ Despite the fact that the causes of this genocide were apparent, no commendable steps were taken by the international community, in particular the United Nations, to avert it. ${ }^{3}$

The seeds of abhorrence, intrigue, hate and discrimination had been sown in Rwanda for many years, as the international community looked on in disregard. By 1990, the two dominant groups, the Hutu and Tutsi, could no longer peacefully co-exist. Having dominated politically, socially and economically for a long time, the Tutsi were targets of hatred of the emerging Hutu Leadership who felt they had been deprived of leadership positions.

* Research assistant and final year LLB student, Makerere University.

1 A Des Forges Leave none to tell the story: Genocide in Rwanda (1999); B BoutrosGhali (ed) The United Nations and Rwanda 1993-1996 (1996).

2 Norwegian Helsinki Committee for Human Rights 'Prosecuting genocide in Rwanda: The Gacaca system and the International Criminal Tribunal for Rwanda'.

3 'Inquiry says UN inertia in 1994 worsened genocide in Rwanda' New York Times December 1999 A1: 'An international panel of experts issued a strong worded report holding both the United Nations and leading member countries responsible for failing to prevent the genocide in Rwanda. On the part of the UN, Kofi Annan admitted responsibility whereas the Clinton administration seemed to be bent on the defensive asserting that the loss of 18 American Rangers in Somalia in 1993 had scared away the United States from peace keeping particularly in Africa for domestic political reasons. The report showed a pattern of ignored warnings and missed signs of the genocide to come in Rwanda. According to the report, 'information received by a united nations mission that plans are being made to exterminate any group of people requires an immediate and determined response'. 
With tensions already high, it is not surprising that within hours of President Habyarimana's death, Hutu extremist cliques, having already drawn a list of political figures opposed to the government, assisted the Presidential Guard in unleashing systematic terror and killings against the Tutsi. They were assisted by the Rwandan Armed Forces (RAF), ${ }^{4}$ gendarmerie and the Interahamwe. They employed mostly crude methods of killing in their massacres, the most prominent of which was the use of machetes, although sophisticated weaponry was also used.

Having established that 'genocide and other systematic, widespread and flagrant violations of international humanitarian law committed in Rwanda constituted a threat to international peace and security' the UN adopted Resolution 955 which established the International Criminal Tribunal for Rwanda (ICTR). ${ }^{5}$ The ICTR was largely inspired by the International Criminal Tribunal for the former Yugoslavia (ICTY), a similar institution established for bringing those responsible for similar atrocities committed in the former Yugoslavia to justice.

It has been almost fifteen years since the ICTR was established. By November 2008, the ICTR had delivered 31 judgments in respect of 37 accused, with 5 ongoing trials and 5 awaiting judgment deliveries. ${ }^{6}$ There are, however, 13 fugitives at large with one fugitive awaiting trial. These are arguably remarkable achievements for a tribunal that began in the face of difficult circumstances amidst many logistical and infrastructural challenges.

By virtue of the UN Security Council Resolution 1503, the ICTR was mandated to formalise a strategy for completion of all investigations by the end of 2004, all trial activities at first instance by the end of 2008 and all its work by 2010 . These expectations have not been met by the ICTR, as by June 2008 there were still new and pending arrests as well as new trials. Although the ICTR's mandate has been extended to the end of $2009,{ }^{7}$ it is very unlikely that it will have accomplished its designated tasks by then. It is for this reason that the ICTR has attracted levelled criticism from different circles with some calling for its end.

The regular army of Rwanda until the RPF took over power in 1994.

UN Security Council Resolution 955 of 1994

http://www.ictr.org/default.htm (accessed 3 February 2009). Letter from the President of the International Criminal Tribunal for Rwanda, Justice Dennis Byron, addressed to the President of the Security Council, dated 21 November 2008, on the ICTR's completion strategy.

7 UN Security Council Resolution 1824 of 2008 
The ICTR has been largely criticised for taking too long when trying to dispose of the cases before it. ${ }^{8}$ At an international level, it is said that many funds are being spent on the ICTR without showing any results. These criticisms do not take the logistical, political and social challenges faced by the ICTR into account. At the time of its establishment, the ICTR faced mainly infrastructural challenges, thus it took almost three years for the ICTR to decide its first case. ${ }^{9}$ Most of its time was spent on putting an ICTR facility with three chambers in place. The wide-ranging criticisms tend to overshadow the achievements of the ICTR, which are highlighted in this paper.

\section{Historical and political context of the 1994 Rwandan genocide}

\subsection{Brief on the root causes}

There is a debate over the causes of the 1994 genocide in Rwanda, although the political and historical events in Rwanda before the genocide are less contested. What is clear is that these events had a strong bearing on the outbreak of the genocide. Thus, in delivering judgements in its first trial cases, the ICTR started to examine the events which led to the outbreak of the 1994 genocide. ${ }^{10}$

Historically, pre-colonial Rwanda was constituted by three major groups; the Hutu, Tutsi and the Twa. These groups, though distinct in some ways, spoke the same language - Kinyarwanda. The Hutu were and still are dominant in terms of numbers whereas the Twa remain the least dominant. The latter are believed to be the initial inhabitants of Rwanda with hunting and gathering as their way of life. The Hutu arrived after the Twa with farming as their dominant

Such sentiments have been echoed by mostly the Rwandan government as well as other actors. The Rwandan government prides the recently established Gacaca courts as more efficient than the ICTR contending that these courts have disposed of many cases in a rather short time compared to the well facilitated ICTR. Importantly however, it should be noted that these courts operate in rather different contexts and cannot be evaluated in the same light as the ICTR.

9 The first judgment was delivered in Prosecutor $v$ Akayesu ICTR-96-4-T on 2 September 1998, almost four years since its establishment in 1994.

10 Prosecutor $v$ Akayesu ICTR-96-4-T paras 78-111; Prosecutor $v$ Kayishema and Ruzindana ICTR-95-1-A para 31. In these cases the learned judges in delivering judgment made reference to the events leading up to the 1994 genocide. They traced the polarisation of the Rwandan society along ethnic lines as a creation of the colonial powers that had subsequently found its way into peoples thinking. With division of society along ethnic lines society became even more conscious of the differences between the two most predominant tribes and eventually the quest for power and supremacy between these two led to even more polarisation, which formed a fertile ground for the 1994 genocide. The ICTR therefore used the trend of events to imply specific intent, the mens rea, for genocide. It found that in the quest for power and supremacy, the accused persons, who were mainly Hutu, engaged in plans to destroy and do away with the Tutsi race. This formed the specific intent and was the basis of convictions at the ICTR. 
occupation. The Tutsi were the final group to arrive, forming the Rwanda polity. It became apparent that with the arrival of the Tutsi, there were renewed social implications and for this reason it is important to briefly venture into the origin of these people and how this could have influenced and shaped social relations in this community and eventually ended with the 1994 genocide.

The origin of the Tutsi is shrouded in mystery. It has been argued that they are superior non-Bantu of Hamitic origin who conquered the indigenous Hutu pastoralists and Twa gatherers. According to Mamdan, however, there is no consensus amongst historians and anthropologists on the real origin of the Tutsi. ${ }^{11}$

The history and origin of the Tutsi is important,

not because of where the Batutsi originally came from, but because in their coming together they created certain political institutions which outlived that history and shaped a tragic future ... The key political institution forged through their contact was the pre-colonial Rwanda state. It established a double domination of a pastoralist aristocracy over a subject peasantry, and of Batutsi, Bahutu and Batwa. ${ }^{12}$

The Tutsi were clearly portrayed as a distinct and advantaged flock over the ordinary Hutu and Twa. It is consciousness of this fact that partly triggered hate sentiments between the Tutsi and the Hutu, although at this stage a real catalyst had not been applied. This catalyst was to take the form of colonial interference in politics of Rwanda in favour of one group over the other.

Aside from their rather distinct origins, once these groups or castes ${ }^{13}$ united under the Kingdom of Rwanda, in what has come to be known as the state of Rwanda, they shared what came to be a tragic history. ${ }^{14}$ What should be noted at this stage, however, is that in postcolonial Rwanda, there was no segregation along ethnic lines. Distinction was rather based on class and individual reference. The word Tutsi was associated with the elite and rich cattle keepers. A Hutu agriculturalist could attain Tutsi status by acquiring cows upon the conclusion of the Ubuhake contact. ${ }^{15}$

Similarly the Hutu were 'Tutsified' upon the grant of land by the King of Rwanda in whom all land vested. This process was known as ijikingi (royal land concession). Moreover, through the process of on Rwanda' (1996) 216 New Left Review 6.

12 Mamdani (n 11 above) 8.

13 D'Hertefelt Le Rwanda (1962) 16; The author describes these groups as castes defining a caste as a hereditary, endogamous group with a specific occupation, structured in a hierarchical system.

14 With the Tutsi cattle keepers conquering, infiltrating and assimilating into the society of the Hutu cultivators, they established the Kingdom of Rwanda.

15 The Ubuhake represented a contract between a Shebuja (patron) and a Mugaragu (client) concerning the fief of a cow. 
kwihutura a Hutu who was able to accumulate lots of cattle could shed his 'Hutuness' and achieve a Tutsi political status. This then prevented caste-like differences in pre-colonial Rwanda, making the difference more of a political distinction. This, unlike ethnic differentiation, entailed that one divided the subject from the nonsubject population; it was not a social economic distinction between exploiters and the exploited or the rich and the poor. This differentiation along political lines prevented the Batutsi-Bahutu distinction from hardening into a caste-like difference and the formation of a counter-Hutu elite that would in time challenge Tutsi domination. ${ }^{16}$

Despite the fact that both the Tutsi and Hutu spoke the same language and lived in the same community, they were yet to become one people. ${ }^{17}$ The Kingdom of Rwanda as compared to other kingdoms was highly centralised. Its undoing was that unlike other centralised kingdoms, such as Buganda, rulers and subjects belonged to two distinct social groups - pastoralist and agriculturist, one noble and the other commoner. The king and war lords were largely Tutsi, despite the fact that the whole population was affiliated to the army.$^{18}$ It has also been said that 'the corpse of a Mututsi had more value than that of a Muhutu or Mutwa ... the Bahutu were deprived of the right to a glorious, honourable, heroic death, since the Batutsi had also social monopoly on that. ${ }^{, 19}$

\subsection{Rwanda in the advent of colonialism: A recipe for future disaster}

The advent of colonialism in Rwanda witnessed an alteration to precolonial Rwanda. First, Rwanda was under German colonial administration from 1897, and then under Belgian administration from 1917 - following the defeat of Germany, Belgium was given the mandate by the League of Nations to govern Rwanda. Both colonial governments adopted a system of indirect rule in Rwanda with the Tutsi playing a dominant role. In the minds of the colonisers, the elite Tutsi looked more like them because of their height and colour, and they were therefore thought to be more intelligent and better equipped to govern than their Hutu counterparts. ${ }^{20}$

16 Mamdani (n 12 above) 10.

17 There was also some sort of power sharing between the Tutsi and the Hutu. The Chief of men, who was in charge of recruiting soldiers, would be either Tutsi or Hutu while the chief of pastures, who ruled over grazing lands, was more likely to be Tutsi and the chief of land holding a Hutu. What was clear however was that non-Tutsi functionaries were common in the lower administrative ranks.

18 Mamdani (n 12 above) 9.

19 A Lema 'Africa divided: The creation of ethnic groups', unpublished PhD thesis, University of Lund 199353.

20 Prosecutor $v$ Akayesu ICTR-96-4-T paras 78-111. 
With colonialism came economic exploitation. In order to sustain the colonial government, there was a push for a more productive economy. This was to be ensured through the cultivation of cash crops as well as forced labour. With the Tutsi occupying the most dominant positions in the colonial government, they were made 'enforcers' of the colonial government agenda. Their role was to ensure that the Hutu agriculturalists produce at high scale, failing which the Hutu could lose their land. This sparked more resentment for 'Tutsi rule' by the Hutu.

Polarisation of the Rwandan polity along ethnic lines became more evident with the introduction of identity cards by the Belgian authorities in 1930. These cards made reference to an individual's ethnic background, and it was not until after 1994 that they were abolished. ${ }^{21}$ The effect of these cards was to clearly distinguish one group from the other. It is not surprising therefore that the perpetrators of the genocide could identify their targets based on these cards.

The Catholic Church, like the colonial government, maintained an unequal community. It afforded the Tutsi elite preferential treatment by giving them privileged access to education and training. This was done by the Church with the intention of converting the Tutsi to Christianity. Unfortunately for the Catholic Church, this objective was not met and it resorted to attempting to convert the Hutu, who were more willing to convert for strategic reasons. At this point the Hutu were able to access education that was formerly reserved for the Tutsi.

Nonetheless, the Tutsi remained stronger than the other groups and by 1940 they started demanding independence. Due to these demands, both the colonial government and the church changed their allegiance from the Tutsi to the Hutu. This, coupled with increased pressure from the United Nations Trusteeship Council to groom natives and prepare them for independence, forced the colonial government to grant more opportunities to the Hutu in education and senior positions in government services.

The culmination of renewed hatred between the two groups became even more evident with the 1956 general elections that saw the most dominant political positions taken by the Hutu. ${ }^{22}$ Universal adult suffrage threatened any future Tutsi political domination, thus creating even more tension between these two groups. By 1959, the Tutsi and Hutu confronted each other violently in a quest for dominance. Being the dominant group at the time, the Hutu exiled the Tutsi monarch and declared themselves rulers of the Republic of

22 L Maguire 'Ethnecised: The pursuit of protection and participation in Rwanda and Burundi' (1995) 49 Bufallo Journal of International Law 53. 
Gitarama in 1961. ${ }^{23}$ Amidst this oppression, most Tutsi fled to neighbouring countries. Rwanda now had an independent Hutu president. 24

At this point the Hutu clearly dominated politically, socially and economically, thus altering the post-colonial Rwandan structure. This was achieved through censure of Tutsi activities as well as the banning of all political parties until early 1990. This dominance and Tutsi oppression served to amplify resentment and opposition from the hitherto superior Tutsi, who formed counter pressure groups including the Rwandan Patriotic Front (RPF). ${ }^{25}$ The RPF mostly comprised of excombatants of the Ugandan National Resistance Army (NRA) that had toppled the Obote administration in Uganda, and they were well experienced and facilitated. Most of them were Tutsi refugees that had fled to Uganda following the Hutu oppression and had consequently joined the NRA to gain a form of recognition. ${ }^{26}$

The Hutu administration noticed that the RPF was an equally strong force, and with increased international pressure to introduce multi-party politics and find a peaceful end to the conflict, the Hutu engaged the RPF and a series of agreements were entered into. ${ }^{27}$ At this point however, the seeds of suspicion and hatred had already been sown and not even international diplomacy could tame tensions between the two ethnic groups. It was during this time that the Rwandan President, Habyarimana, was killed when the aircraft carrying him and his Burundian counterpart was brought down. This incident marked the beginning of a most horrific genocide in the history of mankind. ${ }^{28}$ The resulting conflict had become ethnicised, with one group threatening to wipe out the other. This is what came to be known as the 1994 Rwanda Genocide, orchestrated mainly by the Hutu's against the Tutsi.

Following the overwhelming success of the Hutu dominated anti-monarch Parti du Movuvement d' L' Emancipation Hutu (PARMEHUTU) in the 1960 elections, the monarchy was abolished in favour of a republic. See C Watson Exile from Rwanda: Background to an Invasion (1991).

24 C Watson Exile from Rwanda: Background to an Invasion (1991).

25 Maguire (n 22 above) 57.

26 It is however said that this recognition was not achieved and for this reason they deemed it necessary to return back home, this time as combatants.

27 These initiatives took place notwithstanding the Hutu administration under president Habyarimana arming supporters against their enemies - the Tutsi. This was coupled with a violent propaganda campaign orchestrated largely by the private owned Radio Télévision Libre des Mille Collines (RTLM). In its communications, the radio called upon the Hutu to kill their enemies, referring to them as traitors. Human Rights Watch Genocide in Rwanda (1994) 2.

28 Prosecutor v Akayesu ICTR-96-4-T paras 103-106; Prosecutor $v$ Kayishema and Ruzindana ICTR-95-1-A paras 53-54. 


\section{The Outbreak of the 1994 Rwanda genocide}

Even as the negotiations were going on, Hutu extremists were already arming themselves in preparation for a Tutsi massacre. Machetes were reportedly shipped from China for this purpose. ${ }^{29}$ Propaganda and hate messages against the Tutsi had been spread on Radio Rwanda and later Radio Télévision Libre des Mille Collines (RTLM) and this served to heighten the existing animosity between the two groups. ${ }^{30}$ These acts continued throughout the genocide.

It is therefore not surprising that, following the death of President Habyarimana, Hutu extremists not only took advantage of the consequent chaos and confusion but also deliberately contributed to creating and maintaining a state of anarchy. An 'interim government' was formed within hours of the aircrash and barricades were reportedly set up within 45 minutes. ${ }^{31}$ This newly formed 'interim government' then launched its systematic campaign of genocide against the Tutsi with the support of the Presidential Guard, the RAF, the gendarmerie, and the Interahamwe.

The 1994 Rwandan genocide involved the commission of horrific atrocities against the Tutsi population in the form of massacres across the country. Thousands of Tutsi were blatantly murdered in broad daylight in buildings, notably churches, schools and hospitals. Machetes were also widely used, especially by the civilian Interahamwe Hutu extremists, although sophisticated weapons were also applied in various places across the country. ${ }^{32}$ These killing methods were largely designed to inflict maximum pain and suffering on the victims and this objective was achieved to a large extent, since victims are still recovering to the present day.

It should be noted that although the Tutsi were the predominant targets, some moderate Hutus also fell victim. In many instances Hutus from mixed families were forced to eliminate their Tutsi relatives, and those suspected of giving protection to the Tutsi were considered to be traitors and were eliminated alongside the Tutsi.

29 Africa Rights Rwanda: Death, Despair and Defiance (1994) 61. OAU Report (29 May 2000) paras 7.27-7.31.

30 Prosecutor $v$ Akayesu ICTR-96-4-T; In particular, see the statement by A Desforges.

31 R Degni-Segui 'Report on the situation of human rights in Rwanda' (1994) 7.

32 Africa Rights (n 29 above) 61. 


\section{Understanding the ICTR: Establishment, mandate and mode of operation}

The ICTR, also referred to as the Genocide Tribunal, was established in 1994 for the sole purpose of:

prosecuting persons responsible for the genocide and other violations of international humanitarian law committed in the territory of Rwanda and Rwandan citizens responsible for genocide and other such violations committed in the territory of neighboring state ... ${ }^{33}$

Following in the footsteps of the International Criminal Tribunal for the former Yugoslavia (ICTY) and having considered reports of the special rapportuer for Rwanda and the commission of experts, ${ }^{34}$ and also realising that the situation in Rwanda constituted a threat to international peace and security pursuant to Chapter VII of the UN Charter, the Security Council adopted Resolution 955, thereby establishing the ICTR.

The Security Council was convinced that the prosecution of the persons responsible for heinous crimes committed during the genocide would contribute to national reconciliation and restoration of peace in Rwanda. Initially the Rwandan government petitioned the council for the establishment of an international tribunal. ${ }^{35}$ The same government, however, later voted against the resolution which established the ICTR. ${ }^{36}$ This was the first challenge the ICTR was to confront, since the will and cooperation of Rwanda with the ICTR was vital for the successful implementation of its mandate. Rwanda nevertheless pledged to cooperate with the ICTR, although it has fallen short in fulfilling this promise. ${ }^{37}$

The establishment of the ICTR was unique in that traditional mechanisms were not necessarily followed by establishing this

33 UN Security Council Resolution 955 of 1994.

34 Reports of the Special Rapportuer for Rwanda of the United Nations Commission on Human Rights (UN Document S/1994/1157), annex I-II, and the Report of the Commission of Experts (UN Document S/1994/1157) clearly indicated that genocide and other human rights violations of international humanitarian law had been committed in Rwanda. Also see UN Security Counsel Resolution 955 of 1994. UN Document S/1994/1115.

Considering the resolution inadequate, Rwanda voted against it. On the other hand China abstained from voting. See UN Document S/1995/134, paras 34-45.

37 In some instances Rwanda has been uncooperative with the ICTR, more so where attempts are made to investigate the RPF for crimes committed during the genocide. Prominently, these attempts have been received by the refusal of prosecution witnesses to testify and cooperate with the ICTR. In a letter to the Security Council the prosecution has alleged that this lack of cooperation was a direct consequence of its announcements to investigate the RPF for crimes committed during the genocide (UN Document S/2002/1043). The Rwandan government also reportedly introduced new visa rules for ICTR witnesses resulting in delays. See letters of the President of the ICTR to the Security Council (UN Documents S/2002/847; S/2002/923). 
tribunal. Traditionally, such a process would have involved negotiations at the state level, culminating in a treaty, most likely through the forum of the General Assembly. This would then involve ratification of such a treaty by the states. On the contrary, the ICTR was established as a binding measure of the Security Council facilitated by Rwanda's initial consent and presumed cooperation of other states. Although this was more expedient, ${ }^{38}$ it had many legal implications and its legitimacy had been questioned by defendants on numerous occasions. ${ }^{39}$

\section{Some achievements of the ICTR}

\subsection{Case disposition: Justice delayed is justice denied}

Since its inception, the ICTR has recorded various achievements in terms of investigating and prosecuting cases before it. As of 3 November 2008, the ICTR had delivered 31 judgments of 37 accused persons. ${ }^{40}$ Judgment was awaited in five cases involving eight accused $^{41}$ and there were five ongoing cases in relation to 15 accused. ${ }^{42}$ Furthermore, trials had been concluded in two cases in respect of five accused, although closing arguments in these cases are yet to be heard. Also, five accused ${ }^{43}$ were reported to be awaiting trial and one retrial was expected to take place. ${ }^{44}$

In terms of case disposition, some progress has been made since November 2008. The ICTR's adoption of the joinder of accused persons as a mode of speeding up trial and judgment has been called remarkable. Although initially met with stiff opposition, ${ }^{45}$ it is notable that in instances where more than one person is accused of related crimes, it is only logical to join them for purposes of convenience and expediting the case. This is because in such cases the prosecution may need to rely on the same pieces of evidence and witnesses. This innovation has been critical in reducing the case backlog and has

38 UN Document S/1995/134 para 6.

39 Prosecutor $v$ Kanyabash ICTR-96-15-T.

40 Letter from the President of the International Criminal Tribunal for Rwanda, D Byron, addressed to the President of the Security Council, 21 November 2008, on the ICTRs completion strategy.

41 One such case being Prosecutor v T Bagosora; G Kabiligi; A Ntabakuze; and A Nsengiyumva ICTR-98-41-T.

42 These are largely cases involving more than one accused and include: the 'Butare case' involving P Nyiramasuhuko, AS Ntahobali, S Nsabimana, A Nteziryayo, J Kanyabashi and E Ndayambaje; the 'Military II case' involving A Ndindilyimana, F$X$ Nzuwonemeye, I Sagahutu, and A Bizimungu; the 'Karemera case' involving $E$ Karemera, M Ngirumpatse and J Nzirorera. The other two cases in this category involved C Kalimanzira and E Setako.

43 These include M Bagaragaza, A Ngirabatware, D Ntwawukulilyayo, C Zabonimana and L Nshogoza.

44 This was in respect of T Muvunyi.

45 ICTR press release (ICTR/INFO-2-115) 1 April 1998. 
'reflected more accurately the reality of genocide, an offence that rarely occurs without the involvement of more than one person. ${ }^{46}$

The joinder of accused persons poses its own challenges. In the 'Bagosora case', 47 for example, in their summary judgment, the judges appraised these challenges that included, interpretation of the relevant documents, overwhelming numbers of witnesses, evidence and exhibits and the staff's workload. ${ }^{48}$ Considering the various challenges, and the fact that it took 409 trial days for the ICTR to come up with its judgment notwithstanding, the ICTR should be commended for adopting the procedure of joinder of accused.

While pursuing expedition of cases through developing a clear investigation and prosecution strategy, the ICTR has maintained positive procedural standards as laid out in the ICTR Statute ('the Statute') and ICTR Rules of Procedure and Evidence ('the Rules'). The Statute and Rules put in place a strong witness protection mechanism. ${ }^{49}$ The accused persons' right to counsel is at the ICTR's expense, ${ }^{50}$ and the accused have the right to interpretation ${ }^{51}$ and adequate time to prepare their defence. ${ }^{52}$ Furthermore, the accused are presumed innocent until proved guilty ${ }^{53}$ and trials are conducted without undue delay. ${ }^{54}$ These guarantees are critical in ensuring a fair trial and the ICTR should be commended for upholding these guarantees even when pursuing the speeding up of cases.

\subsection{Interpreting and redefining the crime of genocide and other sexual offences}

One of the most significant and commendable attributes of the ICTR is its jurisprudence on genocide. The ICTR became the first international court to convict an accused person for the crime of genocide. ${ }^{55}$ Under the ICTR Satute, the crime of genocide is defined as any of the following acts committed with the intent to destroy, in whole or in part, a national, ethnical, racial or religious group, as such:

(a) Killing members of the group;

(b) Causing serious bodily or mental harm to members of the group;

C Ciss 'The end of a culture of impunity in Rwanda' (1998) 1 Yearbook of International Humanitarian Law 174.

Prosecutor v Bagosora; G Kabiligi; A Ntabakuze; and A Nsengiyumva ICTR-98-41-T. Prosecutor $v$ Bagosora (n 49 above) para 1.

Art 21 of the ICTR Statute; Rule 75 of the ICTR Rules of Procedure and Evidence. Rule $75(B-C)$ of the ICTR Rules of Procedure and Evidence.

Art 20(4)(f) of the ICTR Statute; Rule 42(ii) of the ICTR Rules of Procedure and Evidence.

Art 20(4)(b)of the ICTR Statute.

Art 20(3) of the ICTR Statute.

Art 20(4)(c) of the ICTR Statute.

Prosecutor v Akayesu ICTR-96-4-T. 
(c) Deliberately inflicting on the group conditions of life calculated to bring about its physical destruction in whole or in part;

(d) Imposing measures intended to prevent births within the group; or

(e) Forcibly transferring children of the group to another group; 56

In Prosecutor $v$ Akayesu ${ }^{57}$ another precedent was set by the ICTR. They defined genocide beyond the above statutory definition. In this case the crime of genocide was redefined to include acts of rape. Although the accused had not been indicted of rape, the indictment was amended to charge him with the rape of Tutsi women who sought refuge at the bureau communal which was under his control. The accused reportedly never raped anyone but had made utterances that could be interpreted to have been aimed at encouraging his subordinates to rape these women. ${ }^{58}$ In that case, rape was defined to mean a physical invasion of a sexual nature committed on a person under circumstances which are coercive. ${ }^{59}$ The ICTR further also redefined the traditional meaning to rape stating that:

Rape is a form of aggression and the central elements of the crime of rape cannot be captured in mechanical description of object and body parts. Like torture, rape is used for such purposes as intimidation, degradation, humiliation, discrimination, punishment, control or destruction of a person. Like torture, rape is a violation of personal dignity. ${ }^{60}$

It was emphasised that sexual violence is not limited to physical invasion of the human body and could include acts which do not involve penetration or even physical contact. ${ }^{61}$

On the evidence presented before the chamber, it was found beyond a reasonable doubt that 'the accused had reason to know and in fact knew that sexual violence was taking place on or near the premises of the bureau communal, and that women were being taken away from the bureau communal and sexually violated'. ${ }^{62}$

The chamber further observed that the accused instigated and aided sexual violence as opposed to taking any measures to prevent such violations or even to punish the perpetrators. In this case it was stated for the first time that rape can constitute genocide if it is committed with the specific intent to destroy, in whole or in part, a particular group, targeted as such. These definitions of rape and sexual violence as set out in Prosecutor $v$ Akayesu were later to be applied in subsequent cases before the ICTR; the most significant

Art 2 of the ICTR Statute. See also art 2 of the Convention on the Prevention and Punishment of the Crime of Genocide.

Prosecutor v Akayesu (n 55 above).

Prosecutor v Akayesu (n 55 above) para 422.

Prosecutor v Akayesu (n 55 above) para 598.

Prosecutor $v$ Akayesu (n 55 above) paras 596-598, 686-688.

Prosecutor $v$ Akayesu (n 55 above).

Prosecutor $v$ Akayesu (n 55 above) para 452. 
being Prosecutor $v$ Musema. ${ }^{63}$ In this case the ICTR stated that rape may include acts of insertion of objects and/or the use of bodily orifices not considered to be intrinsically sexual. To that end it was recommended that in light of trends for the incorporation of rape into principles of international criminal law, a conceptual definition of rape, as opposed to a mechanical definition, should be adopted. In the ICTR's view such a definition is better since it is more accommodating to the evolution of the norms of criminal justice. ${ }^{64}$

However, the ICTR applied a more mechanical definition of rape in the later case of Prosecutor $v$ Semanza. ${ }^{65}$ The Appeals Chamber missed the opportunity to affirm, in clear terms, the conceptual definition. Such a definition would be a strong precedent in international criminal law.

Women and children are the most vulnerable persons in times of conflict and their sexual rights are often abused with impunity. From a human rights perspective, the articulation of rape as an element of genocide can thus be said to strengthen the protection of women's rights as well as group rights where such rape is committed with the specific intent to destroy in whole or in part a particular group. Realising this, the drafters of the Rome Statute of the International Criminal Court ('the Rome Statute') 66 interpreted genocide in a manner similar to that taken in Prosecutor $v$ Akayesu. Under Article 6(b) of the Rome Statute conduct may include rape for the purposes of elements of crimes.

\subsection{Individual criminal and command responsibility and checking the 'kings'}

International law has traditionally been known as the law of nations; however, with the decisions of the ICTR, the notion of individual criminal responsibility has been refurbished. Following the precedent set by the ICTY in Prosecutor $v$ Tadic, ${ }^{67}$ the ICTR has extended the hitherto uncommon principle of individual criminal responsibility. Pursuant to article 6 of the ICTR Statute, the ICTR has reaffirmed

63 Prosecutor $v$ Musema ICTR-96-13-A.

64 Prosecutor $v$ Musema (n 53 above) para 220-221, 226-229.

65 Prosecutor $v$ Semanza ICTR-2001-70-T paras 344-345. The Appeals Chamber adopted a much narrower definition of rape following the ICTY precedent in Prosecutor $v$ Kunarac IT-96-23. The Appeals Chamber constricted rape to nonconsensual penetration, however slight, of the vagina or anus of the victim by the penis of the perpetrator or by an object used by the perpetrator, or of the mouth of the victim by the penis of the perpetrator. It recommended that acts of sexual violence that did not fit within the definition adopted above should be prosecuted as other crimes against humanity.

66 Rome Statute of the International Criminal Court.

67 Prosecutor vTadic IT-94-1-T. 
criminal responsibility for principal perpetrators, abettors, procurers and aiders alike. ${ }^{68}$

Additionally, the ICTR has stated that it applies only where the crime has been committed with the exception of the crime of genocide, provided such crime had actually been committed. ${ }^{69}$ The principle of individual criminal responsibility is positive, as perpetrators of international wrongs can no longer hide behind traditional international law to walk away with impunity.

Related to the above principle is the principle of command responsibility. Pursuant to article 6(3) of the ICTR Statute, the ICTR has also lived to expand on the doctrine of command responsibility. Under this provision, the fact that the offences under the statute were committed by a subordinate does not absolve the superior of criminal responsibility if such a person had knowledge of such acts and the superior failed to take reasonable measures to prevent such acts or to punish the perpetrators. In Prosecutor $v$ Bagilishema ${ }^{70}$ the ICTR outlined the major elements of command responsibility to include:

(i) the existence of a superior subordinate relationship of effective control between the accused and the perpetrator of the crime; and, (ii) the knowledge, or constructive knowledge of the accused that the crime was about to be, was being, or had been committed and, (iii) the failure of the accused to take necessary and reasonable measures to prevent or stop the crime, or to punish the perpetrator.

Aside from vividly expressing itself on elements of command responsibility, the ICTR has set some other general precedents on this principle. In Prosecutor $v$ Kayishema liability for individual criminal responsibility and command responsibility was possible. ${ }^{71}$ In the same case, the chamber noted that the principle applies to civilians and member of the military alike. ${ }^{72}$

Although Jean Kambanda, Prime Minister and caretaker of the government of Rwanda was convicted on his own plea of guilty during the genocide, the decision of the ICTR in his case is laudable. The accused was found to have de jure authority and control over members of his government as a head of state. ${ }^{73}$ As Prime Minister,

Prosecutor v Akayesu (n 55 above) para 472.

69 Prosecutor $v$ Akayesu (n 55 above) para 473. The ICTR, while considering art 6(1) of the ICTR Statute, restated the principle as laid down in Prosecutor $v$ Tadic ( 59 above): 'a person may only be criminally responsible for conduct where it is determined that he knowingly participated in the commission of an offence' and that 'his participation directly and substantially affected the commission of that offence through supporting the actual commission before, during, or after the incident'.

Prosecutor v Bagilishema ICTR-95-1A-I para 38.

Prosecutor $v$ Kayishema ICTR-95-1-A para 210.

Prosecutor $v$ Kayishema (n 71 above) paras 213-215.

Prosecutor $v$ Kambanda ICTR-97-23-S para 39. 
the accused was found to have both de jure and de facto authority over the senior civil servants and army officials. ${ }^{74}$

Whereas the government had the responsibility to maintain peace and security in Rwanda, the accused acted to the contrary, and he failed to take necessary and reasonable measures to prevent his subordinates from committing crimes against the population. ${ }^{75}$ The conviction and sentence of Kambanda therefore emphasises the fact that there are no state immunities for international crimes. ${ }^{76}$ It may be said that the conviction of Kambanda as head of government provided an impetus to the International Criminal Court in indicting Sudanese president, Omar al-Bashir. With this precedent, heads of state will no longer have the luxury of walking away with impunity for crimes committed either at their order or with their knowledge behind the walls of state immunity.

\subsection{Punishments: reconciling ICTR sentences with the aspirations of sentencing}

Justice demands the determination of the allegations made out against a particular party in every trial. The goal of every criminal trial is therefore to determine the liability of the accused person. In the event that a party is found guilty of the offence he or she is charged with, the trial court is expected to sentence such liable party. In the realm of international law, the Nuremberg and Tokyo trials, that were set up to prosecute perpetrators of crimes during the World War II, are very informative in this respect. At Nuremberg, sentences with varying degrees of severity handed down, ranging from to imprisonment to the death penalty. ${ }^{77}$

The sentences imposed by the ICTR appear to be reflective of the sentences imposed by national courts. This is so especially with regard to article 23 of the Statute, which limits penalties to imprisonment and enjoins the ICTR to have recourse to courts of Rwanda in the determination of the terms of a sentence. ${ }^{78}$ Some authors have argued against this provision, maintaining that it is illogical for international courts like the ICTR to impose more or less the same sentences as national courts because international courts deal with 'extraordinary crimes' while national courts deal with 'ordinary crimes'. ${ }^{79}$ The maximum sentence that could be imposed by the ICTR is life imprisonment, while, until recently, the maximum sentence

As above.

Prosecutor $v$ Kambanda (n 73 above) para 44.

Note that previously the extradition of Augusto Pinochet had been denied on grounds of state immunity.

MA Drumbl Atrocity, punishment and international law (2007).

Art 23 of the ICTR Statute.

n 77 above. 
that could be imposed by a Rwandan court was the death penalty. ${ }^{80}$ Even though retribution has been put forward as one of the major theories of punishment, it can be argued that, with the imposition of even lesser sentences than those imposed by the national courts, the ICTR has not lived up to this aspiration. ${ }^{81}$

Unlike the ICTY, the ICTR has been reported to impose harsher sentences. The ICTR has handed down more than ten life imprisonment sentences, while the heaviest sentence, which is currently under appeal, handed down by the ICTY is 32 years imprisonment. ${ }^{82}$ This illustrates the severity of punishments imposed by the ICTR.

\section{Conclusion and recommendations}

Even where the ICTR has fallen short of its expectations, it is only prudent that particular interventions be advanced, not only for the benefit of the ICTR, but also to serve as lessons for similar institutions like the ICC. The ICTR has contributed greatly to the evolution of international criminal law in numerous ways.

The establishment of the ICTR was in itself a landmark. It demonstrated renewed international commitment towards ending impunity and promoting justice and accountability in Africa, which has been depicted as a dark continent where crimes continue to be committed with impunity. Since its establishment, the ICTR has fulfilled its objective of arresting and trying the majority of the de facto leaders of the genocide, with the exception of Felicien Kabuga. ${ }^{83}$ Impunity, which has dogged Africa, is slowly becoming a thing of the past, since state officials now know that they are not above the law. The recent indictment of Bashir, the president of Sudan, by the ICC serves to emphasise this fact.

Over the years the ICTR has improved its case disposition by adopting innovations like the joinder of accused persons. ${ }^{84}$ Although the first cases handled by the ICTR took a relatively long time, later

Art 23 of the ICTR Statute. Rwanda only effectively abolished the death penalty on 25 July 2007 at the insistence of the ICTR, if genocide suspects were to be tried in Rwanda. By the time of abolition however, the ICTR had tried and passed judgment in several cases. At the time the ICTR was seen to be more 'lenient' to perpetrators of genocide.

81 A prisoner once remarked: 'Why is it that the Tribunal gives them more lenient sentences than us; they are the ones who told us to kill on radio... how come we are paying the higher price?'. See 'Arusha tapes amaze Rwandan prisoners: Thousands view documentary on trials of top genocide suspects' Internews 28 May 2001.

82 Drumbl (n 77 above) 56-57; Prosecutor $v$ Brdjanin IT-99-36-A.

83 Felicien Kabuga is considered to have been the chief financier of the genocide. He is suspected to be hiding in Nairobi.

84 Prosecutor v Bagosora (n 47 above). 
cases were and are handled more expeditiously. It is important to note that through the speeding up of cases and developing a clear investigation and prosecution strategy, the ICTR has maintained positive procedural standards, such as witness protection mechanisms ${ }^{85}$ and the right to counsel, ${ }^{86}$ as laid out in the ICTR Statute.

The ICTR will go down in history as the first Tribunal to make a conviction of genocide since the adoption of the 1948 Convention on the Prevention and Punishment of Genocide. ${ }^{87}$ In its first judgment, the Tribunal interpreted the crime of genocide by divulging into its elements in more extensive terms. It is not surprising that some of the conclusions drawn by the ICTR in this judgment in terms of genocide have been incorporated into the Rome Statute. ${ }^{88}$ The ICTR gave a broader interpretation of the 1948 Genocide Convention, noting that genocide cases did not require perpetrators to be state officials, as was the case under the Genocide Convention. ${ }^{89}$ To this end, convictions for genocide were issued in respect of businessmen, Interahamwe and RTLM who were not state officials. Such a limited interpretation would have left most of the perpetrators unpunished, but with the ICTR's pronouncements, they cannot walk away with impunity.

The ICTR's pronouncements on sexual crimes, particularly rape and other gender crimes, constitute a defining moment in international criminal law. For a long time the perception has been that rape and sexual crimes are a 'natural consequence of sending soldiers to war'.90 Sexual crimes have been neglected and discriminated against regardless of the fact that the women against whom they are committed are among the most vulnerable during situations of armed conflict. In its first decision however, the ICTR held rape as a form of aggression and an element of genocide. ${ }^{91}$ This redefinition demonstrates changing paradigms in respect of sexual crimes, and inevitably increases the protection of women during

Art 21 of the ICTR Statute; Rule 75 of the ICTR Rules of Procedure and Evidence. Rule 75 (B-C) of the ICTR Rules of Procedure and Evidence.

Prosecutor $v$ Akayesu (n 55 above).

Art 6 of the Rome Statute of the International Criminal Court.

Prosecutor $v$ Kayishema (n 71 above).

$B$ Bedont et al 'Ending impunity for gender crimes under the International Criminal Court' (1999) 41 The Brown Journal of World Affairs 65-85.

Prosecutor $v$ Akayesu (n 55 above) para 598. In this case rape was given a broader definition to include physical invasion of a sexual nature committed on a person under circumstances that are coercive. Also, sexual violence was defined as any act of a sexual nature that is committed on a person under circumstances that are coercive and such violence it need not be limited to physical invasion. These definitions were subsequently adopted in Prosecutor v Musema ( 55 above) and refined in Prosecutor $v$ Semanza (n 67 above). 
situations of conflict. ${ }^{92}$ The ICTR was the first to convict a head of state $^{93}$ and charge a woman with rape.

The ICTR should be applauded for upholding the concept of individual criminal responsibility. Traditionally, international law has been known as the law of nations but the ICTR's pronouncements on the concept of individual criminal responsibility and the concept of individuals as subjects of international law go a long way in promoting individual accountability for human rights violations.

Notwithstanding the above achievements, the ICTR has had its shortcomings, as already highlighted. These include the slow disposal of cases and procedural glitches, as illustrated in Prosecutor $v$ Barayagwiza. ${ }^{94}$ Criticisms against the ICTR have been that it is costly and too slow in case disposal. In the same vein, it has been argued that the ICTR is far removed from the actual victims of the genocide.

Another weakness relates to the ICTR's mandate. It was obliged to contribute to the process of national reconciliation and to the restoration and maintenance of peace in Rwanda. ${ }^{95}$ This is an objective that can only be achieved where victims feel that justice has been done. Earlier it had been suggested that some of the trials be conducted in Rwanda as a way of giving Rwandans a new sense of ownership of the trials. ${ }^{96}$ Because the impact of the ICTR has not readily been felt among Rwandans demonstrates that the ICTR does not have an effective outreach programme.

While it is not the responsibility of judges to write history, the legal process can help to uncover and better understand it. History is critical in reconciliation processes for polities like Rwanda, left torn apart by genocide. Whereas the guilty pleas entered by some of the accused persons before the ICTR could have paved the way for national reconciliation, the fact that they remain discrete undermines their capacity to do so. The ICTR has affirmed its commitment to the establishment of an historical record of events that is impartial, objective and thorough, but it is yet to achieve this objective. ${ }^{97}$ The ICTR, in determining cases, was restricted to events that occurred between 1 January 1994 and 31 December 1994. Events before 1 January 1994 are omitted and restricted to background information.

Provisions have also been made in the Rome Statute of the International Criminal Court following the decision in Prosecutor v Akayesu (n 57 above) and increased lobbying and women advocacy. See arts 6-8. This illustrates commitment to punishing gender crimes and protection of women during conflict.

Prosecutor $v$ Kambanda (n 75 above). In this case Kambanda, prime minister and head of state, following the death of Habyarimana, was convicted and sentenced to life imprisonment on his own plea of guilty, making him the first head of government to be convicted by an international tribunal. Prosecutor v Barayagwiza ICTR-97-19.

Preamble to the ICTR Statute.

'International Crisis Group Africa Report' 30 (7 June 2001) 30.

'International Crisis Group Africa Report' (n 96 above) 27. 
To those who blame colonial rule for the outbreak of the genocide, for example, this is a disappointment.

As part of the ICTR's completion strategy (completing all cases by 2010), some of the cases were to be transferred to national jurisdictions. Nonetheless, only two deferrals have been granted while the majority of the applications for transfer of cases, particularly to Rwanda, have been denied. These have been largely on grounds of incompetence and impartiality of the Rwandan judiciary as well as non-compliance with international human rights standards. If the ICTR were to transfer some of the cases to Rwandan national courts, it would give victims the satisfaction that justice is done. To that end, the ICTR and the Rwandan government should work towards strengthening the capacity of the Justice, Law and Order Sector ('the JLOS') of Rwanda, particularly the judiciary and detention centres. The genocide contributed to capacity gaps in the Rwandan judiciary - most members of the bench and the bar were either murdered or fled the country. Post-genocide Rwanda was characterised by a judiciary with a lot of capacity deficiencies, and which is largely seen as being partial to the incumbent RPF government.

The ICTR can introduce intensive and tailored training programmes for officers and members of the judiciary in Rwanda, particularly in respect of international criminal law and international human rights, drawing on its rich experience and expertise accumulated over the years. This way a more knowledgeable and human rights sensitive judiciary can be built in Rwanda. It is only when a competent, impartial and effective judiciary is in place that accused persons can be assured of a fair trial and the protection of their fundamental rights and freedoms.

To complement the judiciary, steps should be taken to overhaul and prepare other key sectors within the JLOS. These include giving the police a role in investigations and in prisons. Detention facilities in Rwanda have been criticised for their solitary confinement conditions of detention. Although the death penalty was abolished in Uganda, Rwandan Minister of Justice, Tharcisse Karugarama, said the following about detention conditions: 'They will be tough in that they [criminals] will regret not having been hanged. ${ }^{98}$ This demonstrates reluctance on the part of the government to conform to internationally recognised standards of detention.

The ICTR should also strengthen legal cooperation initiatives with national courts in Rwanda. An information exchange between the two legal systems should also be initiated to prepare the Rwandan judiciary for the eventual transfer of cases. For purposes of other 
jurisdictions where accused persons are found, the ICTR should encourage such states to adapt national laws, as Belgium has, to give them the universal right to try perpetrators of genocide.

The obligation of the ICTR to contribute to the process of national reconciliation and to the restoration and maintenance of peace in Rwanda cannot be overemphasised. The ICTR has tried to achieve this by punishing and preventing genocide. However, the investigation and prosecution of alleged RPF atrocities will determine to the realisation of this objective, given that over the years, opinions have been expressed to the effect that the ICTR is meant to legitimise the Kagame regime and to deflect responsibility. This view of the ICTR can only be clarified by investigating and prosecuting the alleged RPF atrocities. ${ }^{99}$ In this way, the ICTR will be able to assert its impartiality and independence from any government, more so the RPF regime. Such a step would also restore trust in the ICTR, especially among the Hutu, who have dominated the list of the accused persons before the ICTR. It is thus recommended that, before its closure, the ICTR should initiate this process so that it may be carried on after the ICTR has concluded its work.

It should be noted that, as the ICTR moves towards the final stages of the completion strategy, proliferation of judgments, especially at first instance, will be inevitable. It is expected that most of these judgments will be appealed; hence there is a strong need for expansion of the appeals chamber to deal with the increased appeals.

The ICTR cannot operate in a vacuum. Rwanda and the larger international community, as well as the UN Security Council are equally important in the consolidation of the achievements of the ICTR and in building a lasting legacy for the ICTR. Political will and support of the incumbent Rwandan government towards reforms in the legal system and the upholding of human rights are critical. It is therefore not surprising that even during the course of the ICTR's operations withdrawal of support from the Rwandan government almost brought the ICTR's work to a halt. ${ }^{100}$ The government of Rwanda should assure security for witnesses as well as suspects, and above all, create a conducive environment for the prosecution of transferred cases. Such an environment is one where witnesses for the accused can freely give their testimonies without fear of being victimised for harbouring 'genocide ideology' punishable under Rwandan law. ${ }^{101}$

OAU Report 'Rwanda: The preventable genocide' CM 2048 (LXVII).

'Rwanda rounds on genocide tribunal' BBC News 24 July 2002.

Preamble and Art 20 of the Rwanda Constitution 2003. Genocidal ideology is not defined but Art 13 of the Constitution specifies that revisionism, negationism, and the minimization of genocide are punishable by law. 
It is also recommended that the Rwandan government assist the work of the ICTR as much as possible and give guarantees of cooperation in relation to crimes committed by members of the RPF in 1994. This should take place by immediately suspending suspects from official functions, demobilising them and handing them over to the ICTR for trial.

Member States of the UN should also assist the ICTR in the investigation and seizure of suspects, and put diplomatic pressure on those who are suspected of providing refuge or protection to suspects on their territory, such as Kenya (concerning Kabuga), CongoBrazzaville and DRC (converning Bizimungu, Ntiwiragabo, Mpiranya and Renzaho) and Cameroon (concerning Mpiranya). The UN Security Council and Secretariat should pass a resolution obliging all states that have tolerated the presence of known fugitives on their territory to make a serious effort to arrest and transfer those persons to Arusha, under threat of sanctions.

Post-conflict realities pose many complex economic, political and social challenges that cannot be adequately solved by an isolated approach. It requires an amalgamation of various approaches and political will to thwart all major impediments to peace and reconciliation. The ICTR should thus be assessed in this context, as it does not operate in a vacuum.

It should be noted that there cannot be peace without justice and there cannot be justice where human rights violations continue to occur without redress. The ICTR, regardless of its weaknesses, has done a commendable job in dispensing justice to victims of the 1994 Rwanda genocide and in bringing those responsible for committing atrocities to justice. This legacy set by the ICTR should be deepened and consolidated through numerous interventions. One such intervention is the building of a competent, independent and effective judiciary in Rwanda that guarantees international human rights standards in order to deal with cases that may not have been disposed of by the ICTR at the time of its conclusion. 